\title{
Determinants of Systemic Risk of Banks in India
}

\author{
Mihir Dash \\ School of Business, Alliance University
}

Received: Jan. 2, 2019 Accepted: June 5, 2019 Published: June 5, 2019

doi:10.5296/ajfa.v11i1.14157 URL: https://doi.org/10.5296/ajfa.v11i1.14157

\begin{abstract}
This study examines the determinants of systemic risk for banks in India. The independent variables considered for the study include the sector, bank size, return on assets, beta, leverage, capital adequacy, non-performing assets, price to book value, deposits, loans \& advances, investments, net interest income, and non-interest income. A mixed panel regression model was applied, with bank fixed effects and year random effects.

The results of the study indicate that public sector banks have a much higher level of systemic impact than private sector banks. Further, the determinants of systemic impact are different for public sector and private sector banks. The systemic impact of public sector banks was positively related with size and negatively related with price to book value ratio and investments to total assets ratio, while the systemic impact of private sector banks was negatively related with return on assets and positively related with beta and net interest income to total funds ratio.
\end{abstract}

Keywords: systemic risk, determinants, public sector banks, private sector banks. 


\section{Introduction}

Systemic risk represents the impact that the failure of a bank or financial institution would have on the entire financial system and/or economy, through its network of interlinked financial intermediaries. The failure of an institution leads to financial stress on institutions that have lent money to it, which in turn may lead to failure of some of these institutions. this leads to a kind of domino or ripple effect, and spreads across the entire financial system.

The recent experience of the global financial crisis of 2008-09 and the subsequent Euro-zone crises of 2010-11 has demonstrated the importance of measuring the level of systemic risk associated with different financial institutions and understanding the factors contributing to systemic risk. The collapse of some of the most prominent banks in the world, including the Lehman Brothers and Washington Mutual Bank, along with several near-failures which had to be bailed out of crisis by the U.S. Government, highlighted the significance of understanding, measuring, and monitoring systemic risk.

Several economists have suggested that undercapitalisation of large financial institutions can result in financial instability, particularly when the entire financial system is undercapitalised. This is leads to the concept of "too big to fail" (TBTF), i.e. that large financial institutions are so systemically important that they cannot be allowed to fail. A similar concept is that of "too interconnected to fail" (TICTF), i.e. that financial institutions that are highly inter-connected with other institutions are very systemically important and so cannot be allowed to fail.

A question that several authors have posed is: which financial institutions should be bailed out in the event of a solvency/liquidity crisis (e.g. Acharya et al, 2012)? This logically requires identifying which institutions are critical to stability of the financial system, i.e. "systemically important." According to the Basel Committee on Banking Supervision (BCBS), the concept of systemic importance should be measured in terms of the potential impact of the failure of a bank on the global financial system and wider economy, rather than just the risk that a failure can occur (Moore and Zhou, 2014).

There are many theories suggesting that large and complex banks contribute to systemic risk. A possible root for the systemic importance of large, inter-connected banks is moral hazard; as regulators are reluctant to close or unwind large and complex banks, this leads banks to take on excessive risks in the expectation of government bailouts (e.g., Farhi and Tirole, 2012). Another possibility is that of agency effects, i.e. that poor governance of large and complex banks can lead to bank managers engaging in non-traditional risky activities (for example, trading) and tend to be financed more through short-term debt, making them more vulnerable to liquidity shocks and market failures (e.g. Laeven and Levine, 2007; Boot and Ratnovski, 2012).

The Indian banking system, which was initially hailed to be unaffected by the crises, was affected indirectly, mainly on account of growing trade and financial integration with the global economy. Though Indian banks were not pushed to the point of insolvency, monitoring of systemic risk has become important in the dynamic banking environment in India in order to avoid potential system failure. This study examines the determinants of systemic risk for Indian 
banks.

The Indian banking industry has two important segments, public sector banks and private sector banks. Public sector banks are owned and controlled by the government, and are subjected to political interference and constraints. Many studies have argued that private sector banks outperform public sector banks due to professional, efficient management, and better customer focus and service, particularly in terms of Management Soundness and Earnings and Profitability (Dash and Das, 2013; Dash et al, 2015). In view of this, the determinants of systemic risk would be expected to differ between public sector and private sector banks.

\section{Literature Review}

\section{Measurement of Systemic Risk}

There are many definitions of systemic risk and systemic importance advocated in the literature, and many more approaches proposed for their measurement.

Adrian and Brunnermeier (2008) was one of the first authors to suggest a measure for systemic risk, viz. the conditional value-at-risk (CoVaR), which focuses on the tail distribiution. They were able to identify the contribution of each bank to systemic risk using this measure.

Acharya et al (2010a, 2010b) proposed the concept of systemic expected shortfall (SES), i.e. the amount by which a bank is undercapitalised in a systemic event in which the entire financial system is undercapitalised, to measure systemic risk. Acharya and Steffan (2012) extended the framework by introducing the concepts of marginal expected shortfall (MES), which measures the performance of a bank when the market return as a whole experiences its worst $5 \%$ trading days within a year, and the bank's market leverage ratio (LVG), the market value of assets divided by the market value of equity.

Brownlees and Engle $(2012,2017)$ and Acharya et al (2012) suggested the SRISK index, which estimates the expected capital shortage of a bank during on a substantial market meltdown, as a measure for systemic risk.

Hautsch et al $(2013,2015)$ used a parsimonius econometric approach to measure systemic risk, the realised systemic risk beta, viz. the total effect of a bank's VaR on the VaR of the entire financial system, taking into account the bank's network relationships.

Suh et al (2013) proposed a method for estimating systemic risk using credit default swaps. Their method had the added advantage of being able to measure systemic risk contributions in both directions, i.e. the overall effect of systemic risk on individual credit risks and vice versa.

Karimalis and Nomikos (2014) proposed a methodology for estimating the CoVaR, i.e. the Value-at-Risk of the financial system conditional on the failure of a financial institution based on copula functions, and extended this approach to estimate other conditional risk measures such as Conditional Expected Shortfall (CoES).

Moore and Zhou (2014) proposed the expected system loss (ESL), viz. the expected loss to the financial system as a whole given that a particular bank fails, which they estimated using multivariate extreme value theory, as a measure of systemic importance of the bank. 
Hattori et al (2014) pointed out that systemic risk measures are essentially a form of scenario analysis, as they analyse the impact of certain types of assumed trigger events on the financial system, based on past patterns of failure; however, this may not be an indicator for robustness against future, unprecedented modes of failure. Also, they argued that most market-based estimates of systemic risk may overestimate the importance of short-term changes. They suggested combining different systemic risk measures together with macro-stress testing scenarios, providing a wider range of potential sources of failure.

van Oordt and Zhou (2015) analysed bank systemic risk into two dimensions, the level of bank tail risk and the linkage between the level of bank tail risk and severe financial shocks to the system.

\section{Determinants of Systemic Risk}

Several studies have analysed the determinants of systemic risk and systemic importance of banks.

Stolbov (2012) examined macro-determinants of systemic risk for some major economies. He found that gross government debt to GDP, state fragility index, EU membership, and world gross GDP share are key determinants of systemic risk for the sovereign CDS prices, while stock market total value traded to GDP, state fragility index, and financial openness index are the key determinants of systemic risk in the stock market.

Moore and Zhou (2014) found that size and non-traditional banking activities were the significant determinants of systemic importance of US banks in the period 2000-10; in particular, they found that banks above a certain size have equal systemic importance.

Bostandzic et al (2014) found that banks with higher levels of Tier 1 capital had lower exposure and contribution to global systemic risk. Further, they found that bank size and interconnectedness are positively related to global financial fragility. They also found that deposit insurance schemes that require banks and depositors to bear more financial risk are associated with greater vulnerability and contribution to a crisis of the financial sector.

van Oordt and Zhou (2015) found that banks with higher non-performing loan ratios and lower profitability ratios tended to have higher tail risk, while larger banks, with higher trading revenue, and higher non-interest income tend to have higher systemic risk.

Laeven et al (2016) found that systemic risk increases with bank size and is inversely related with bank capital; in particular, low capital in large banks is the key driver of systemic risk. Further, they found that market-based activities and country characteristics have moderating effect on these relationships.

Anghelache and Oanea (2016) found that financial leverage, size, risk, and market to book value had a significant impact on systemic risk contribution of Romanian commercial banks.

\section{Methodology}

The objective of the study is to analyse the determinants of systemic risk for banks in India. Due to the wide differences in performance between public sector and private sector banks, the 
determinants of systemic risk would be expected to differ between public sector and private sector banks.

The study was conducted using sample of thirty-one Indian banks, including twenty-one public sector banks, and ten private sector banks. The list of sample banks is given in the table below.

\begin{tabular}{|l|l|}
\hline Public sector banks & Private sector banks \\
\hline Allahabad Bank & Axis Bank Ltd \\
\hline Andhra Bank & Federal Bank Ltd \\
\hline Bank of Baroda & HDFC Bank Ltd \\
\hline Bank of India & ICICI Bank Ltd \\
\hline Bank of Maharashtra & IndusInd Bank Ltd \\
\hline Canara Bank & Jammu \& Kashmir Bank Ltd \\
\hline Central Bank of India & Karnataka Bank Ltd \\
\hline Corportaion Bank & Karur Vysya Bank Ltd \\
\hline Dena Bank & Kotak Mahindra Bank Ltd \\
\hline IDBI Bank Ltd & Yes Bank Ltd \\
\hline Indian Overseas Bank & \\
\hline Punjab \& Sind Bank & \\
\hline Punjab National Bank & \\
\hline State Bank of Bikaner \& Jaipur & \\
\hline State Bank of India & \\
\hline State Bank of Mysore & \\
\hline State Bank of Travancore & \\
\hline Syndicate Bank & \\
\hline United Commercial Bank & \\
\hline Union Bank of India & \\
\hline Vijaya Bank & \\
\hline
\end{tabular}

The data pertaining to bank characteristics was collected from the Capitaline database ${ }^{1}$. The SRISK estimates were collected from NYU Stern's V-Lab database ${ }^{2}$. The study period was 2007-16.

The dependent variable considered for the study is the measure of systemic risk proposed by Brownlees and Engle (2012), SRISK. This index measures the expected capital shortage faced by a bank during a period of system distress when the market declines substantially. It is estimated as

$$
S R I S K_{i, t}=k D_{i, t}-(1-k) W_{i, t}\left(1-L R M E S_{i, t+h \mid t}\left(C_{t+h \mid t}\right)\right)
$$

where $\mathrm{k}$ is the minimum fraction of capital (as a ratio of total assets) each bank needs to hold, $\mathrm{D}_{\mathrm{i}, \mathrm{t}}$ and $\mathrm{W}_{\mathrm{i}, \mathrm{t}}$ are the book value of its debt (total liabilities) and the market value of its equity,

\footnotetext{
1 www.Capitaline.com

https://vlab.stern.nyu.edu/analysis/RISK.WORLDFIN-MR.GMES
} 
respectively, and the long-run marginal expected shortfall LRMES is defined as the tail expectation of the firm's equity return conditional on a market decline

$$
L R M E S_{i, t+h \mid t}=-E_{t}\left(R_{i, t+h \mid t} \mid R_{m, t+h \mid t}<C\right) .
$$

Note that SRISK can take negative values. A bank with negative SRISK represents a wellcapitalised bank with large enough capital buffers to easily absorb systemic shocks. The total systemic risk in the financial system is measured by aggregating the positive SRISK contributions of different financial institutions.

The independent variables considered for the study ae discussed in the following.

The most common determinant for systemic risk is that of bank size, and the commonly-used proxy for size is the logarithm of the bank's total assets (see for example, Laeven et al, 2014). The systemic risk of a bank would be expected to increase with bank size. This reflects the "too big to fail" hypothesis, that the failure of a large bank would have too a great impact on the entire financial system, so that government should intervene to prevent such a failure.

Another common determinant is capital adequacy (Laeven et al, 2014). The measure for capital adequacy used for the study is the Capital Adequacy Ratio. It is expected that higher levels of capital adequacy would be associated with a lower systemic impact.

Non-performing loans is an important determinant (van Oordt and Zhou, 2015), and would be expected to play a role in increasing systemic risk particularly for public sector banks. The measure considered in the study is the Net Non-Performing Loans to Net Advances.

Two other important determinants are beta and leverage (Anghelache and Oanea, 2016). These have also been included in the present study. Both would be expected to be positively related with systemic impact.

Bank profitability may also be related with systemic impact. In the present study, it is measured by the return on assets of the bank.

Non-interest income has been found to be a significant determinant of systemic impact in several studies (Moore and Zhou, 2013; van Oordt and Zhou, 2015), positively related with systemic impact. This was measured in the present study using the Non-Interest Income to Total Funds ratio. Along with this, the Net Interest Income to Total Funds ratio is also considered.

Laeven et al (2014) have also considered deposits to total assets and loans \& advances to total assets in their analysis. These have also been included in the present study, along with investments to total assets.

Bostandzic et al (2014) have also considered the valuation ratios as potential determinants of systemic impact. The price to book value ratio has been considered in the present study.

The study used a mixed panel regression model for explaining systemic risk, formulated as follows: 


$$
\operatorname{SRISK}_{i, t}=a+\sum_{i} b_{i}(1+S) x_{i, t}+\sum_{i} c_{i} D_{i}+\sum_{t} d_{t} D_{t}+\epsilon_{i, t}
$$

where the dependent variable on the LHS is the SRISK of the ith bank at time point $t, \mathrm{x}_{\mathrm{i}, \mathrm{t}}$ are the independent variables for the ith bank at time point $t, S$ represents a dummy variable for public sector banks $(S=1)$ against private sector banks $(S=0)$, the $D_{i}$ represent the individual bank dummies, in order to capture the bank fixed effect, and the Dt represent the year dummies, in order to capture the year random effect.

\section{Findings}

The descriptive statistics for the variables are presented in Table 1 below.

Table 1. descriptive statistics of SRISK and its determinants

\begin{tabular}{|c|c|c|c|c|c|c|c|c|}
\hline & \multicolumn{4}{|c|}{ private sector } & \multicolumn{4}{|c|}{ public sector } \\
\hline & Mean & St. Dev. & Min & Max & Mean & St. Dev. & Min & Max \\
\hline SRISK (\$ m) & -2841.41 & 5079.93 & -25319 & 3100 & 1940.70 & 2120.98 & -122 & 14521 \\
\hline In(Total Assets) & 13.63 & 1.11 & 11.62 & 15.80 & 14.32 & 0.86 & 12.50 & 16.93 \\
\hline Return on Assets & 1.39 & 0.40 & 0.34 & 2.02 & 0.72 & 0.51 & -1.25 & 2.50 \\
\hline Beta & 0.84 & 0.27 & 0.24 & 1.57 & 0.80 & 0.22 & 0.22 & 1.41 \\
\hline Leverage & 8.50 & 6.05 & 1.89 & 27.68 & 29.31 & 15.92 & 7.83 & 103.85 \\
\hline Capital Adequacy Ratio & 14.78 & 2.33 & 11.03 & 22.46 & 11.92 & 1.05 & 9.44 & 15.00 \\
\hline Net Non-Performing Assets to Net Advances & 0.83 & 0.81 & 0.00 & 4.31 & 1.99 & 1.77 & 0.15 & 11.89 \\
\hline Price to Book Value Ratio & 2.47 & 1.79 & 0.46 & 9.58 & 0.87 & 0.42 & 0.26 & 2.70 \\
\hline Deposits to Total Assets & 0.76 & 0.11 & 0.52 & 0.90 & 0.84 & 0.05 & 0.42 & 0.91 \\
\hline Loans \& Advances to Total Assets & 0.58 & 0.04 & 0.47 & 0.68 & 0.62 & 0.03 & 0.51 & 0.70 \\
\hline Investments to Total Assets & 0.30 & 0.04 & 0.20 & 0.43 & 0.26 & 0.03 & 0.16 & 0.34 \\
\hline Net Interest Income to Total Funds & 3.15 & 0.86 & 1.07 & 5.62 & 2.46 & 0.52 & 0.59 & 3.66 \\
\hline Non-Interest Income to Total Funds & 1.61 & 0.52 & 0.52 & 2.63 & 0.97 & 0.27 & 0.45 & 1.83 \\
\hline
\end{tabular}

The private sector banks had a negative average SRISK and a negatively-skewed distribution of SRISK, while the public sector banks had a positive average SRISK and a positively-skewed distribution of SRISK. Private sector banks also had higher return on assets, capital adequacy, price to book value ratios, net interest income to total funds, and non-interest income to total funds than public sector banks, while public sector banks had higher leverage and net nonperforming assets to net advances than private sector banks. There was not much of a difference between public and private sector banks in terms of size, beta, deposits to total assets, loans \& advances to total assets, and investments to total assets.

The results of the panel regression are presented in Tables 2 and 3 below. Table 2 presents the summary of statistical tests for groups and covariates, while Table 3 presents the parameter estimates and significance. 
Table 2. Tests of Between-Subjects Effects

\begin{tabular}{|c|c|c|c|c|}
\hline \multicolumn{5}{|l|}{ Dependent Variable: SRISK (\$ m) } \\
\hline & \multicolumn{2}{|c|}{ Model I } & \multicolumn{2}{|c|}{ Model II } \\
\hline Source & F Stat & p-value & F Stat & p-value \\
\hline Intercept & 7.078 & 0.008 & 16.165 & 0.000 \\
\hline bank & 8.586 & 0.000 & 15.359 & 0.000 \\
\hline year & 4.310 & 0.000 & 5.710 & 0.000 \\
\hline In(Total Assets) & 9.330 & 0.003 & 11.150 & 0.001 \\
\hline sector $* \ln ($ Total Assets $)$ & 28.447 & 0.000 & 78.262 & 0.000 \\
\hline Return on Assets & 14.857 & 0.000 & 25.459 & 0.000 \\
\hline sector * Return on Assets & 13.317 & 0.000 & 15.552 & 0.000 \\
\hline Beta & 34.197 & 0.000 & 46.760 & 0.000 \\
\hline sector $*$ Beta & 21.806 & 0.000 & 33.223 & 0.000 \\
\hline Leverage & 1.954 & 0.163 & 1.941 & 0.165 \\
\hline sector * Leverage & 4.057 & 0.045 & 4.391 & 0.037 \\
\hline Capital Adequacy Ratio & 0.591 & 0.443 & & \\
\hline sector * Capital Adequacy Ratio & 0.820 & 0.366 & & \\
\hline Net Non-Performing Assets to Net Advances & 0.000 & 0.993 & & \\
\hline sector * Net Non-Performing Assets to Net Advances & 1.084 & 0.299 & & \\
\hline Price to Book Value Ratio & 14.025 & 0.000 & 17.062 & 0.000 \\
\hline sector * Price to Book Value Ratio & 11.546 & 0.001 & 15.256 & 0.000 \\
\hline Deposits to Total Assets & 0.892 & 0.346 & 2.323 & 0.129 \\
\hline sector * Deposits to Total Assets & 5.737 & 0.017 & 5.098 & 0.025 \\
\hline Loans \& Advances to Total Assets & 3.574 & 0.060 & & \\
\hline sector * Loans \& Advances to Total Assets & 1.233 & 0.268 & & \\
\hline Investments to Total Assets & 3.091 & 0.080 & & \\
\hline sector * Investments to Total Assets & 0.082 & 0.775 & & \\
\hline Net Interest Income to Total Funds & 8.432 & 0.004 & 6.576 & 0.011 \\
\hline sector * Net Interest Income to Total Funds & 9.893 & 0.002 & 6.955 & 0.009 \\
\hline Non-Interest Income to Total Funds & 0.913 & 0.340 & & \\
\hline sector * Non-Interest Income to Total Funds & 0.978 & 0.324 & & \\
\hline
\end{tabular}


Table 3. Parameter Estimates

\begin{tabular}{|c|c|c|c|c|c|c|}
\hline \multicolumn{7}{|c|}{ Dependent Variable: SRISK (\$ m) } \\
\hline Parameter & Coeff & t Stat & p-value & Coeff & t Stat & p-value \\
\hline Intercept & 4397.226 & 0.257 & 0.797 & -10578.643 & -0.852 & 0.395 \\
\hline Allahabad Bank & -76113.340 & -4.481 & 0.000 & -70040.480 & -6.933 & 0.000 \\
\hline Andhra Bank & -74703.558 & -4.447 & 0.000 & -68478.262 & -6.895 & 0.000 \\
\hline Axis Bank Ltd & -3637.858 & -2.230 & 0.027 & -3469.793 & -2.294 & 0.023 \\
\hline Bank of Baroda & -79996.195 & -4.608 & 0.000 & -73454.769 & -6.868 & 0.000 \\
\hline Bank of India & -78701.873 & -4.537 & 0.000 & -72351.973 & -6.820 & 0.000 \\
\hline Bank of Maharashtra & -73313.242 & -4.409 & 0.000 & -67396.971 & -6.906 & 0.000 \\
\hline Canara Bank & -78607.887 & -4.521 & 0.000 & -72674.861 & -6.863 & 0.000 \\
\hline Central Bank of India & -76482.713 & -4.487 & 0.000 & -70938.551 & -6.917 & 0.000 \\
\hline Corporation Bank & -75233.326 & -4.459 & 0.000 & -69225.172 & -6.928 & 0.000 \\
\hline Dena Bank & -73311.008 & -4.425 & 0.000 & -66986.663 & -6.895 & 0.000 \\
\hline Federal Bank Ltd & 1974.807 & 1.447 & 0.149 & 1783.790 & 1.481 & 0.140 \\
\hline HDFC Bank Ltd & -14842.406 & -7.445 & 0.000 & -13858.932 & -7.273 & 0.000 \\
\hline ICICI Bank Ltd & -9110.329 & -3.916 & 0.000 & -8845.393 & -4.288 & 0.000 \\
\hline IDBI Bank Ltd & -76973.519 & -4.515 & 0.000 & -71788.620 & -7.102 & 0.000 \\
\hline Indian Overseas Bank & -76908.534 & -4.523 & 0.000 & -70738.764 & -6.956 & 0.000 \\
\hline IndusInd Bank Ltd & -456.462 & -0.469 & 0.639 & -31.621 & -0.037 & 0.971 \\
\hline Jammu \& Kashmir Bank Ltd/The & 4129.962 & 2.244 & 0.026 & 5258.616 & 3.245 & 0.001 \\
\hline Karnataka Bank Ltd/The & 3002.203 & 2.006 & 0.046 & 3046.984 & 2.278 & 0.024 \\
\hline Karur Vysya Bank Ltd/The & 6283.394 & 3.750 & 0.000 & 5914.837 & 4.157 & 0.000 \\
\hline Kotak Mahindra Bank Ltd & -6245.489 & -4.194 & 0.000 & -6393.232 & -4.480 & 0.000 \\
\hline Punjab \& Sind Bank & -71849.270 & -4.363 & 0.000 & -65983.535 & -6.852 & 0.000 \\
\hline Punjab National Bank & -79229.726 & -4.530 & 0.000 & -73249.639 & -6.838 & 0.000 \\
\hline State Bank of Bikaner \& Jaipur & -72529.804 & -4.385 & 0.000 & -65696.653 & -6.836 & 0.000 \\
\hline State Bank of India & -78764.352 & -4.310 & 0.000 & -72869.284 & -6.336 & 0.000 \\
\hline State Bank of Mysore & -71165.576 & -4.319 & 0.000 & -64565.665 & -6.790 & 0.000 \\
\hline State Bank of Travancore & -72212.815 & -4.357 & 0.000 & -66164.736 & -6.863 & 0.000 \\
\hline Syndicate Bank & -76269.478 & -4.495 & 0.000 & -70422.623 & -6.922 & 0.000 \\
\hline United Commercial Bank & -75788.491 & -4.486 & 0.000 & -70006.842 & -6.934 & 0.000 \\
\hline Union Bank of India & -77423.677 & -4.495 & 0.000 & -71365.530 & -6.860 & 0.000 \\
\hline Vijaya Bank & -74417.073 & -4.475 & 0.000 & -68716.606 & -7.024 & 0.000 \\
\hline Yes Bank Ltd & $0^{\mathrm{a}}$ & & & $0^{\mathrm{a}}$ & & \\
\hline [year $=2007$ ] & 6722.166 & 4.062 & 0.000 & 7065.554 & 4.861 & 0.000 \\
\hline [year $=2008$ ] & 6388.592 & 4.283 & 0.000 & 6702.933 & 5.156 & 0.000 \\
\hline [year $=2009$ ] & 5575.231 & 4.254 & 0.000 & 5793.970 & 5.238 & 0.000 \\
\hline [year=2010] & 4680.356 & 4.150 & 0.000 & 4689.801 & 4.862 & 0.000 \\
\hline [year $=2011]$ & 4913.351 & 4.730 & 0.000 & 4849.746 & 5.649 & 0.000 \\
\hline
\end{tabular}


Asian Journal of Finance \& Accounting ISSN 1946-052X 2019, Vol. 11, No. 1

\begin{tabular}{|c|c|c|c|c|c|c|}
\hline$[$ year=2012] & 4049.743 & 4.963 & 0.000 & 3671.839 & 5.644 & 0.000 \\
\hline$[$ year $=2013]$ & 2428.967 & 3.468 & 0.001 & 1952.050 & 3.460 & 0.001 \\
\hline [year=2014] & 1573.958 & 2.660 & 0.008 & 1002.343 & 2.099 & 0.037 \\
\hline$[$ year $=2015]$ & 566.039 & 1.070 & 0.286 & 412.203 & 0.874 & 0.383 \\
\hline [year=2016] & $0^{\mathrm{a}}$ & & & $0^{\mathrm{a}}$ & & \\
\hline ln(Total Assets) & 5066.337 & 4.252 & 0.000 & 5462.618 & 5.254 & 0.000 \\
\hline$[$ sector $=0] * \ln ($ Total Assets $)$ & -4332.851 & -5.334 & 0.000 & -5020.016 & -8.847 & 0.000 \\
\hline$[$ sector $=1] * \ln ($ Total Assets $)$ & $0^{\mathrm{a}}$ & & & $0^{\mathrm{a}}$ & & \\
\hline Return on Assets & -131.243 & -0.242 & 0.809 & -683.160 & -1.723 & 0.086 \\
\hline [sector $=0] *$ Return on Assets & -3871.904 & -3.649 & 0.000 & -2838.175 & -3.944 & 0.000 \\
\hline [sector $=1] *$ Return on Assets & $0^{\mathrm{a}}$ & & & $0^{\mathrm{a}}$ & & \\
\hline Beta & 2302.747 & 2.292 & 0.023 & 2342.717 & 2.377 & 0.018 \\
\hline$[$ sector $=0] *$ Beta & 6221.938 & 4.670 & 0.000 & 7214.696 & 5.764 & 0.000 \\
\hline$[$ sector $=1] *$ Beta & $0^{\mathrm{a}}$ & & & $0^{\mathrm{a}}$ & & \\
\hline Leverage & -17.468 & -1.138 & 0.256 & -19.551 & -1.294 & 0.197 \\
\hline [sector $=0] *$ Leverage & 131.409 & 2.014 & 0.045 & 129.460 & 2.096 & 0.037 \\
\hline [sector $=1] *$ Leverage & $0^{\mathrm{a}}$ & & & $0^{\mathrm{a}}$ & & \\
\hline Capital Adequacy Ratio & 10.027 & 0.070 & 0.944 & & & \\
\hline [sector $=0]$ * Capital Adequacy Ratio & -165.643 & -0.905 & 0.366 & & & \\
\hline [sector $=1] *$ Capital Adequacy Ratio & $0^{\mathrm{a}}$ & & & & & \\
\hline $\begin{array}{l}\text { Net Non-Performing Assets to Net } \\
\text { Advances }\end{array}$ & 256.942 & 1.512 & 0.132 & & & \\
\hline $\begin{array}{l}\text { [sector }=0] * \text { Net Non-Performing } \\
\text { Assets to Net Advances }\end{array}$ & -509.354 & -1.041 & 0.299 & & & \\
\hline $\begin{array}{l}\text { [sector }=1] * \text { Net Non-Performing } \\
\text { Assets to Net Advances }\end{array}$ & $0^{\mathrm{a}}$ & & & & & \\
\hline Price to Book Value Ratio & -2492.467 & -3.717 & 0.000 & -2732.728 & -4.170 & 0.000 \\
\hline$[$ sector $=0]$ * Price to Book Value Ratio & 2353.533 & 3.398 & 0.001 & 2657.621 & 3.906 & 0.000 \\
\hline [sector $=1]$ * Price to Book Value Ratio & $0^{\mathrm{a}}$ & & & $0^{\mathrm{a}}$ & & \\
\hline Deposits to Total Assets & 5194.245 & 1.046 & 0.297 & 2474.266 & .540 & 0.589 \\
\hline [sector $=0] *$ Deposits to Total Assets & -17527.892 & -2.395 & 0.017 & -15445.471 & -2.258 & 0.025 \\
\hline [sector $=1] *$ Deposits to Total Assets & $0^{\mathrm{a}}$ & & & $0^{\mathrm{a}}$ & & \\
\hline Loans \& Advances to Total Assets & -6438.208 & -0.856 & 0.393 & & & \\
\hline $\begin{array}{l}\text { [sector }=0] * \text { Loans \& Advances to } \\
\text { Total Assets }\end{array}$ & -16477.730 & -1.110 & 0.268 & & & \\
\hline $\begin{array}{l}\text { [sector }=1] * \text { Loans \& Advances to } \\
\text { Total Assets }\end{array}$ & $0^{\mathrm{a}}$ & & & & & \\
\hline Investments to Total Assets & -15264.478 & -1.902 & 0.058 & & & \\
\hline $\begin{array}{l}\text { [sector }=0] * \text { Investments to Total } \\
\text { Assets }\end{array}$ & 3935.368 & 0.286 & 0.775 & & & \\
\hline $\begin{array}{l}\text { [sector }=1] * \text { Investments to Total } \\
\text { Assets }\end{array}$ & $0^{\mathrm{a}}$ & & & & & \\
\hline
\end{tabular}




\begin{tabular}{|l|r|r|r|r|r|r|}
\hline Net Interest Income to Total Funds & 1.879 & 0.004 & 0.997 & 27.788 & 0.057 & 0.954 \\
\hline $\begin{array}{l}\text { [sector=0] * Net Interest Income to } \\
\text { Total Funds }\end{array}$ & 2338.908 & 3.145 & 0.002 & 1827.424 & 2.637 & 0.009 \\
\hline $\begin{array}{l}\text { [sector=1] * Net Interest Income to } \\
\text { Total Funds }\end{array}$ & $00^{\mathrm{a}}$ & & & 0 & & \\
\hline Non-Interest Income to Total Funds & 1199.327 & 1.346 & 0.180 & & & \\
\hline $\begin{array}{l}\text { [sector=0] * Non-Interest Income to } \\
\text { Total Funds }\end{array}$ & -1161.044 & -0.989 & 0.324 & & & \\
\hline $\begin{array}{l}\text { [sector=1] * Non-Interest Income to } \\
\text { Total Funds }\end{array}$ & $0^{\mathrm{a}}$ & & & & & \\
\hline
\end{tabular}

a. This parameter is set to zero because it is redundant.

There were several significant factors in the model. The bank fixed effects were found to be significant, indicating that there were significant differences in systemic impact between the banks. In particular, the banks with highest systemic impact were Karur Vysaya Bank, Jammu and Kashmir Bank, and Karnataka Bank (all of which are private sector banks), while the banks with least systemic impact were Bank of Baroda, Punjab National Bank, and State Bank of India (all of which are public sector banks). The year random effects were also found to be significant, indicating significant differences in systemic impact over time. Of course, systemic impact was highest in the crisis period of 2007-09, and there was found to be a significant decrease in systemic impact in 2015-16 as compared with previous years. This could be the result of tightening of capital regulations with the implementation of the Basel III norms from 2013.

Bank size was found to be significant and positively related with systemic impact; however, for private sector banks, the relationship was not significant. Return on assets was found to be not significant; however, for private sector banks, return on assets was significant and negatively related with systemic impact. Beta was found to be significant and positively related with systemic impact, and was more influential for private sector banks than for public sector banks. Leverage was found to be not significant; however, for private sector banks, leverage was significant and positively related with systemic impact. Price to Book Value Ratio was found to be significant and negatively related with systemic impact; however, for private sector banks, the relationship was not significant. Deposits to Total Assets was found to be not significant; however, for private sector banks, deposits to total assets was significant and negatively related with systemic impact. Net Interest Income to Total Funds was found to be not significant; however, for private sector banks, net interest income to total funds was significant and positively related with systemic impact. Finally, Capital Adequacy Ratio, Net Non-Performing Assets to Net Advances, Loans \& Advances to Total Assets, Investments to Total Assets, and Non-Interest Income to Total Funds were found to be not significant.

The results of the panel regression for public sector banks are presented in Tables 4 and 5 below. Table 4 presents the summary of statistical tests for groups and covariates, while Table 5 presents the parameter estimates and significance. 
Table 4. Tests of Between-Subjects Effects (public sector banks)

\begin{tabular}{|l|r|r|}
\hline Dependent Variable: SRISK (\$ m) & \multicolumn{1}{|l|}{} \\
\hline Source & \multicolumn{1}{|c|}{ F Stat } & p-value \\
\hline Intercept & 9.594 & 0.002 \\
\hline bank & 4.349 & 0.000 \\
\hline year & 2.749 & 0.005 \\
\hline In(Total Assets) & 12.073 & 0.001 \\
\hline Return on Assets & 0.423 & 0.517 \\
\hline Beta & 2.679 & 0.104 \\
\hline Leverage & 2.274 & 0.134 \\
\hline Capital Adequacy Ratio & 0.002 & 0.965 \\
\hline Net Non-Performing Assets to Net Advances & 0.000 & 0.985 \\
\hline Price to Book Value Ratio & 30.831 & 0.000 \\
\hline Deposits to Total Assets & 1.376 & 0.243 \\
\hline Loans \& Advances to Total Assets & 0.283 & 0.595 \\
\hline Investments to Total Assets & 4.275 & 0.040 \\
\hline Net Interest Income to Total Funds & 0.578 & 0.448 \\
\hline Non-Interest Income to Total Funds & 1.328 & 0.251 \\
\hline
\end{tabular}

Table 5. Parameter Estimates (public sector banks)

\begin{tabular}{|l|r|r|r|}
\hline \multirow{2}{*}{ Dependent Variable: SRISK (\$ m) } & \multicolumn{2}{l|}{} \\
\hline Parameter & \multicolumn{1}{l|}{} \\
\hline Intercept & \multicolumn{1}{c|}{ Coeff } & \multicolumn{1}{c|}{ t Stat } & \multicolumn{1}{c|}{ p-value } \\
\hline Allahabad Bank & -71514.348 & -3.165 & 0.002 \\
\hline Andhra Bank & -1636.940 & -1.490 & 0.138 \\
\hline Bank of Baroda & -498.757 & -0.662 & 0.509 \\
\hline Bank of India & -5312.641 & -2.351 & 0.020 \\
\hline Bank of Maharashtra & -3961.561 & -1.796 & 0.075 \\
\hline Canara Bank & 885.432 & 1.439 & 0.152 \\
\hline Central Bank of India & -3998.239 & -1.922 & 0.056 \\
\hline Corporation Bank & -1851.295 & -1.293 & 0.198 \\
\hline Dena Bank & -789.810 & -0.917 & 0.361 \\
\hline IDBI Bank Ltd & 1155.592 & 1.930 & 0.055 \\
\hline Indian Overseas Bank & -2325.580 & -1.312 & 0.191 \\
\hline Punjab \& Sind Bank & -2119.980 & -1.557 & 0.122 \\
\hline Punjab National Bank & 2290.483 & 2.409 & 0.017 \\
\hline State Bank of Bikaner \& Jaipur & -4745.687 & -1.930 & 0.055 \\
\hline State Bank of India & 1528.728 & 1.893 & 0.060 \\
\hline State Bank of Mysore & -4157.103 & -0.987 & 0.325 \\
\hline & 3082.076 & 3.305 & 0.001 \\
\hline
\end{tabular}




\begin{tabular}{|l|r|r|r|}
\hline State Bank of Travancore & 1802.566 & 2.713 & 0.007 \\
\hline Syndicate Bank & -2135.242 & -1.753 & 0.082 \\
\hline United Commercial Bank & -1231.812 & -1.160 & 0.248 \\
\hline Union Bank of India & -2984.208 & -1.779 & 0.077 \\
\hline Vijaya Bank & $0^{\mathrm{a}}$ & & \\
\hline [year=2007] & 5795.819 & 2.747 & 0.007 \\
\hline [year=2008] & 5619.692 & 2.895 & 0.004 \\
\hline [year=2009] & 3876.008 & 2.379 & 0.019 \\
\hline [year=2010] & 3913.768 & 2.838 & 0.005 \\
\hline [year=2011] & 3228.041 & 2.742 & 0.007 \\
\hline [year=2012] & 2342.197 & 2.710 & 0.007 \\
\hline [year=2013] & 1449.163 & 2.124 & 0.035 \\
\hline [year=2014] & 326.312 & 0.604 & 0.547 \\
\hline [year=2015] & -415.003 & -0.830 & 0.408 \\
\hline [year=2016] & $0^{\mathrm{a}}$ & & \\
\hline In(Total Assets) & 5198.187 & 3.475 & 0.001 \\
\hline Return on Assets & -250.612 & -0.650 & 0.517 \\
\hline Beta & 1290.967 & 1.637 & 0.104 \\
\hline Leverage & -16.780 & -1.508 & 0.134 \\
\hline Capital Adequacy Ratio & -4.500 & -0.044 & 0.965 \\
\hline Net Non-Performing Assets to Net Advances & -2.493 & -0.019 & 0.985 \\
\hline Price to Book Value Ratio & -2920.455 & -5.553 & 0.000 \\
\hline Deposits to Total Assets & 4212.420 & 1.173 & 0.243 \\
\hline Loans \& Advances to Total Assets & -2880.443 & -0.532 & 0.595 \\
\hline Investments to Total Assets & -11938.625 & -2.068 & 0.040 \\
\hline Net Interest Income to Total Funds & 322.384 & 0.760 & 0.448 \\
\hline Non-Interest Income to Total Funds & 747.846 & 1.153 & 0.251 \\
\hline a & & & \\
\hline
\end{tabular}

a. This parameter is set to zero because it is redundant.

For the public sector banks, the bank fixed effects were again found to be significant, indicating that there were significant differences in systemic impact between the banks. In particular, the banks with highest systemic impact were State Bank of Mysore, Punjab \& Sind Bank, and State Bank of Travancore, while the banks with least systemic impact were Bank of Baroda, Punjab National Bank, and State Bank of India. The year random effects were also found to be significant, again indicating a significant decrease in systemic impact in 2015-16 as compared with previous years. Further, for the public sector banks, bank size was found to be significant and positively related with systemic impact, while price to book value ratio and investments to total assets ratio were found to be significant and negatively related with systemic impact. The other variables were not significantly related with systemic impact.

The results of the panel regression for private sector banks are presented in Tables 4 and 5 below. Table 4 presents the summary of statistical tests for groups and covariates, while Table 5 presents the parameter estimates and significance. 


\section{Macrothink}

Table 6. Tests of Between-Subjects Effects (private sector banks)

\begin{tabular}{|l|r|r|}
\hline Dependent Variable: SRISK (\$ m) & \multicolumn{1}{|l|}{} \\
\hline Source & \multicolumn{1}{|c|}{ F Stat } & \multicolumn{1}{|l|}{ p-value } \\
\hline Intercept & 0.024 & 0.877 \\
\hline bank & 10.667 & 0.000 \\
\hline year & 2.884 & 0.006 \\
\hline In(Total Assets) & 1.661 & 0.202 \\
\hline Return on Assets & 8.509 & 0.005 \\
\hline Beta & 18.668 & 0.000 \\
\hline Leverage & 0.020 & 0.888 \\
\hline Capital Adequacy Ratio & 0.146 & 0.704 \\
\hline Net Non-Performing Assets to Net Advances & 0.411 & 0.524 \\
\hline Price to Book Value Ratio & 0.000 & 0.994 \\
\hline Deposits to Total Assets & 1.134 & 0.291 \\
\hline Loans \& Advances to Total Assets & 0.024 & 0.877 \\
\hline Investments to Total Assets & 10.667 & 0.000 \\
\hline Net Interest Income to Total Funds & 2.884 & 0.006 \\
\hline Non-Interest Income to Total Funds & 1.661 & 0.202 \\
\hline
\end{tabular}


Table 7. Parameter Estimates (private sector banks)

\begin{tabular}{|c|c|c|c|}
\hline \multicolumn{4}{|l|}{ Dependent Variable: SRISK (\$ m) } \\
\hline Parameter & Coeff & t Stat & p-value \\
\hline Intercept & -7473.603 & -0.273 & 0.785 \\
\hline Axis Bank Ltd & -5928.249 & -2.223 & 0.030 \\
\hline Federal Bank Ltd & 2719.082 & 1.295 & 0.200 \\
\hline HDFC Bank Ltd & -17370.329 & -5.311 & 0.000 \\
\hline ICICI Bank Ltd & -12577.122 & -3.244 & 0.002 \\
\hline IndusInd Bank Ltd & -895.387 & -0.555 & 0.581 \\
\hline Jammu \& Kashmir Bank Ltd/The & 5842.883 & 1.985 & 0.051 \\
\hline Karnataka Bank Ltd/The & 4870.375 & 2.077 & 0.042 \\
\hline Karur Vysya Bank Ltd/The & 8118.748 & 3.035 & 0.003 \\
\hline Kotak Mahindra Bank Ltd & -6581.768 & -2.924 & 0.005 \\
\hline Yes Bank Ltd & $0^{\mathrm{a}}$ & & \\
\hline [year $=\mathbf{2 0 0 7 ]}$ & 8448.572 & 2.765 & 0.007 \\
\hline [year $=\mathbf{2 0 0 8 ]}$ & 7777.578 & 2.960 & 0.004 \\
\hline [year $=2009]$ & 9369.069 & 3.805 & 0.000 \\
\hline [year $=\mathbf{2 0 1 0 ]}$ & 6195.154 & 2.901 & 0.005 \\
\hline [year $=\mathbf{2 0 1 1 ]}$ & 7651.405 & 3.710 & 0.000 \\
\hline [year $=\mathbf{2 0 1 2 ]}$ & 7039.089 & 4.045 & 0.000 \\
\hline [year $=\mathbf{2 0 1 3 ]}$ & 3936.757 & 2.454 & 0.017 \\
\hline [year $=2014]$ & 3357.982 & 2.443 & 0.017 \\
\hline [year $=\mathbf{2 0 1 5 ]}$ & 1173.581 & 1.014 & 0.314 \\
\hline [year $=\mathbf{2 0 1 6 ]}$ & $0^{\mathrm{a}}$ & & \\
\hline In(Total Assets) & 1813.567 & 1.289 & 0.202 \\
\hline Return on Assets & -3963.675 & -2.917 & 0.005 \\
\hline Beta & 9623.341 & 4.321 & 0.000 \\
\hline Leverage & -16.043 & -0.142 & 0.888 \\
\hline Capital Adequacy Ratio & -68.630 & -0.382 & 0.704 \\
\hline Net Non-Performing Assets to Net Advances & 457.091 & 0.641 & 0.524 \\
\hline Price to Book Value Ratio & -2.145 & -0.007 & 0.994 \\
\hline Deposits to Total Assets & -8651.957 & -1.065 & 0.291 \\
\hline Loans \& Advances to Total Assets & -31624.452 & -1.568 & 0.122 \\
\hline Investments to Total Assets & -24602.327 & -1.280 & 0.205 \\
\hline Net Interest Income to Total Funds & 1980.436 & 2.270 & 0.027 \\
\hline Non-Interest Income to Total Funds & 596.284 & 0.460 & 0.647 \\
\hline
\end{tabular}

a. This parameter is set to zero because it is redundant.

For the private sector banks, the bank fixed effects were again found to be significant, indicating that there were significant differences in systemic impact between the banks. In particular, the banks with highest systemic impact were Karur Vysaya Bank, Jammu and Kashmir Bank, and Karnataka Bank, while the banks with least systemic impact were HDFC 
Bank, ICICI Bank, and Kotak Mahindra Bank. The year random effects were also found to be significant, again indicating a significant decrease in systemic impact in 2015-16 as compared with previous years. Further, for the private sector banks, return on assets was found to be significant and negatively related with systemic impact, while beta and net interest income to total funds ratio were found to be significant and positively related with systemic impact. The other variables were not significantly related with systemic impact.

\section{Discussion}

The results of the study have identified some banks with relatively high systemic impact, viz. Karur Vysaya Bank, Jammu and Kashmir Bank, and Karnataka Bank. These banks must be monitored more carefully, and perhaps may be required to hold more capital or liquid assets to avert crisis.

The results of the study also suggest that systemic risk of Indian banks has been declining significantly from 2013. This is perhaps the result of higher capital controls by the RBI with the phased implementation of Basel III norms in India.

The results of the study indicate that public sector banks have a much higher level of systemic impact than private sector banks. Further, the determinants of systemic impact are different for public sector and private sector banks. The systemic impact of public sector banks was positively related with size and negatively related with price to book value ratio and investments to total assets ratio, while the systemic impact of private sector banks was negatively related with return on assets and positively related with beta and net interest income to total funds ratio.

The presence of a size effect for systemic impact in the case of public sector banks suggests that consolidation for public sector banks may increase instability of the financial system. This is not the case for private sector banks, so that private sector bank mergers may be beneficial for systemic risk. This would, however, need to be studied in greater detail.

Several of the findings are similar to those in the literature. Bank size was found to be significant and positively related with systemic impact for public sector banks, as suggested by several authors (Moore and Zhou, 2014; Laeven et al, 2016). Return on assets was found to be significant and negatively related with systemic impact for private sector banks, which is related to the findings of van Oordt and Zhou (2015). Beta was found to be significant and positively related with systemic impact, which is related to the findings of Anghelache and Oanea (2016). Leverage was found to be significant and positively related with systemic impact for private sector banks, as suggested by Anghelache and Oanea (2016). Price to book value ratio was found to be significant and negatively related with systemic impact for public sector banks, as suggested by Anghelache and Oanea (2016). Some findings have not been discussed previously in the literature. For example, deposits to total assets was found to be significant and negatively related with systemic impact for private sector banks; on the other hand, loans $\&$ advances to total assets and investments to total assets were not significant. Also, net interest income to total funds was found to be significant and positively related with systemic impact for private sector banks. On the other hand, some of the findings are contrary to the literature; 
for example, non-interest income to total funds were found to be not significant, contrary to the finding of Moore and Zhou (2014). Finally, two important variables, capital adequacy ratio and net non-performing assets to net advances, were found to be not significant, contrary to the findings of Laeven et al (2016) and van Oordt and Zhou (2014), respectively.

The results of the study suggest that capital adequacy does not have much of an effect on systemic impact, which is contrary to economic logic. This would have to be investigated further to understand the interlinkage between capital adequacy, leverage, liquidity, and other relevant variables. In particular, this would have important policy implications for the regulation of bank capital and leverage.

There are some limitations inherent in the study. The sample considered for the study was relatively small, and consisted of the relatively larger Indian banks. Also, the global financial crisis and Euro-zone crises had taken place during the study period, possibly contaminating the results. Further, there could be some multicollinearity between the variables, since many of the measures considered are related. For example, capital adequacy has improved in recent years, so that the significance of capital adequacy could have been affected by the year random effect. The results of the study thus need to be tested for robustness.

\section{References}

Acharya, V.V., Brownlees, C., Engle, R., Farazmand, F., \& Richardson, M. (2010). Measuring Systemic Risk. in Regulating Wall Street: The Dodd-Frank Act and the New Architecture of Global Finance, edited by Acharya, V.V., Cooley, T., Richardson, M., and Walter, I., John Wiley \& Sons. https://doi.org/10.1002/9781118258231

Acharya, V.V., Engle, R.F., \& Richardson, M. (2012). Capital Shortfall: A new approach to ranking and regulating systemic risks. Presented at the American Economic Association Meeting held at Chicago, Illinois, USA on Jan 7, 2012. https://doi.org/10.1257/aer.102.3.59

Acharya, V.V., Pedersen, L., Philippon, T., \& Richardson, M. (2010). Measuring Systemic Risk. NYU Stern Working Paper. https://doi.org/10.26509/frbc-wp-201002

Acharya, V.V., \& Steffen, S. (2012). Analyzing Systemic Risk of the European Banking Sector. NYU Stern Working Paper. in Handbook on Systemic Risk, edt. J.-P- Fouque and J. Langsam. Cambridge University Press

Adrian, T., \& Brunnermeier, M.K. (2008). CoVaR. Federal Reserve Bank of New York Staff Report No. 348. https://doi.org/10.2139/ssrn.1269446

Anghelache, G.-V., \& Oanea, D.-C. (2016). Romanian Commercial Banks' Systemic Risk and Its Determinants: A CoVaR Approach. International Journal of Academic Research in Accounting, Finance and Management Sciences, 6(3), 96-109. https://doi.org/10.6007/IJARAFMS/v6-i3/2175

Boot, A.W.A., \& Ratnovski, L. (2012). Banking and Trading. International Monetary Fund Working Paper No. 12/238. https://doi.org/10.5089/9781475511215.001

Bostandzic, D., Pelster, M., \& Weiss, G.N.F. (2014). Systemic risk, bank capital, and deposit 
insurance around the world. SSRN Working Paper No. 2438693. https://doi.org/10.2139/ssrn.2438693

Brownlees, C.T., \& Engle, R.F. (2012). Volatility, Correlation and Tails for Systemic Risk Measurement. NYU Stern Working Paper. https://doi.org/10.2139/ssrn.1611229

Brownlees, C.T., \& Engle, R.F. (2017). SRISK: a conditional capital shortfall model for systemic risk. European Systemic Risk Board Working Paper. https://doi.org/10.1093/rfs/hhw060

Dash, M., \& Das, A. (2013). Performance Appraisal of Indian Banks Using CAMELS Rating. IUP Journal of Bank Management, 12(2), 31-42.

Dash, M., Kumari, G., \& Anand, S. (2015). Comparison of Public and Private Sector Banking Performance using CAMELS Framework. MANAGEMENT TODAY-An International Journal of Management Studies, 5(3), 107-112. https://doi.org/10.11127/gmt.2015.09.02

Farhi, E., \& Tirole, J. (2012). Collective Moral Hazard, Maturity Mismatch and Systemic Bailouts. American Economic Review, 12(1), 60-93. https://doi.org/10.1257/aer.102.1.60

Hattori, A., Kikuchi, K., Niwa, F., \& Uchida, Y. (2014). A Survey of Systemic Risk Measures: Methodology and Application to the Japanese Market. IMES Discussion Paper Series, No. 2014-E-3.

Hautsch, N., Schaumburg, J., \& Schienle, M. (2013). Forecasting Systemic Impact in Financial Networks. Syrto Working Paper Series, Paper No. 16/2013. https://doi.org/10.2139/ssrn.2315827

Hautsch, N., Schaumburg, J., \& Schienle, M. (2015). Financial Network Systemic Risk Contributions. Review of Finance, 19(2), 685-738. https://doi.org/10.1093/rof/rfu010

Hendricks, D., Kambhu, J., \& Mosser, P. (2006). Systemic Risk and the Financial System: Background Paper. NAS-FRBNY Conference on New Directions in Understanding Systemic Risk held at Federal Reserve Bank of New York on May 18, 2006.

Karimalis, E.N., \& Nomikos, N. (2014). Measuring systemic risk in the European banking sector: A Copula CoVaR approach. Cass Business School Working Paper.

Laeven, L., \& Levine, R. (2007). Is there a diversification discount in financial conglomerates?" Journal of Financial Economics, 85, 331-367. https://doi.org/10.1016/j.jfineco.2005.06.001

Laeven, L., Ratnovski, L., \& Tong, H. (2016). Bank Size, Capital, and Systemic Risk: Some International Evidence. Journal of Banking and Finance, 69(1), S25-S34. https://doi.org/10.1016/j.jbankfin.2015.06.022

Moore, K., \& Zhou, C. (2014). The Determinants of Systemic Importance. Systemic Risk Centre, London School of Economics, Discussion Paper No. 19.

Stolbov, M. (2017). Assessing systemic risk and its determinants for advanced and major emerging economies: the case of $\Delta \mathrm{CoVaR}$. International Economics and Economic Policy, 
14(1), 119-142. https://doi.org/10.1007/s10368-015-0330-2

Suh, S., Jang, I., \& Ahn, M. (2013). A Simple Method for Measuring Systemic Risk using Credit Default Swap Market Data. Journal of Economic Development, 38(4), 75-100.

van Oordt, M.R.C., \& Zhou, C. (2015). Systemic Risk and Bank Business Models. De Nederlandsche Bank Working Papers, Paper No. 442. https://doi.org/10.2139/ssrn.2509314 